Article

\title{
Molecular Phylogenetics of Trapezia Crabs in the Central Mexican Pacific
}

\author{
Hazel M. Canizales-Flores, Alma P. Rodríguez-Troncoso *, Eric Bautista-Guerrero \\ and Amílcar L. Cupul-Magaña
}

Laboratorio de Ecología Marina, Centro Universitario de la Costa, Universidad de Guadalajara, Av. Universidad No. 203. Puerto Vallarta, Jalisco 48280, Mexico; Hazel_MariaCF@hotmail.com (H.M.C.-F.); ericbguerrero@gmail.com (E.B.-G.); amilcar.cupul@gmail.com (A.L.C.-M.)

* Correspondence: pao.rodriguezt@gmail.com; Tel.: +52-322-226-2319

Received: 15 July 2020; Accepted: 24 August 2020; Published: 26 August 2020

\begin{abstract}
To date, Trapezia spp. crabs have been considered obligate symbionts of pocilloporid corals. They protect their coral hosts from predators and are essential for the health of certain coral species. However, the basic details of this group of crustaceans are lacking, and there is a need for species-level molecular markers. The Tropical Eastern Pacific (TEP) region harbors important coral communities mainly built by corals of the genus Pocillopora, with three known Trapezia species known to associate with them: Trapezia bidentata, T. formosa and T. corallina. Both taxonomic and molecular analyses were carried out with samples of all three crab species collected from Pocillopora spp. in the Central Mexican Pacific. Analysis of both a mitochondrial and a nuclear gene revealed only two species, T. corallina and T. bidentata. T. formosa however appears to be a morphotype of T. bidentata. The use of integrative taxonomy for this group has increased the knowledge of the biodiversity not only of the study area, but of the whole TEP and will enhance the future study of the Trapezia-Pocillopora symbiosis.
\end{abstract}

Keywords: coral reefs; cox1; H3; crustacea; molecular systematics; morphotypes

\section{Introduction}

Coral communities are highly productive ecosystems that harbor a high biodiversity and biomass of small crustaceans [1], among which decapods constitute nearly one-third of the total species [2]. Their relevance is associated not only with the high biomass they represent for the ecosystem, since Crustaceans can affect and/or modify their communities through herbivory, predation, consumption of detritus and nonorganic components and oxygenation of the sediment through burrow construction [3]. Furthermore, crustaceans form numerous, complex trophic relationships that are prone to change in response to both natural and anthropogenic stressors that can threaten the integrity of the coral reef ecosystem, including of crustacean assemblages [4].

Members of the genus Trapezia (Decapoda, Brachyura, Trapeziidae) are ecologically important crustaceans that form obligate symbioses with hermatypic corals of the most widely distributed and abundant genus of the Tropical Eastern Pacific (TEP): Pocillopora [5]. Trapezia crabs live their entire lives, sheltered among the coral branches, providing to the whole colony a defense system against conspecifics and against predators that threaten the coral, such as the corallivorous crown-of-thorns sea star (Acanthaster sp.) [6]. The crabs not only defend the coral, but they remove detritus and promote branch elongation [7]. In exchange, the crabs benefit from the coral-provided shelter, as well as nourishment in the form of the detritus that accumulates in the coral branch mucus [8]. In terms of within-colony Trapezia distribution, there are typically size-based hierarchies in which mature couples dominate and are located among the central branches. Smaller-sized individuals (new recruits, juveniles and even adults) mainly live at the base of the coral colony [8], promoting a hierarchy in 
the use of resources according to the size of the organisms. Due the complex ecological role of the carbs, the Trapezia-Pocillopora relationship is now considered as mutualism rather than an obligate commensalism $[9,10]$.

The distribution of Trapezia predominantly mirrors that of their coral hosts [11]. Despite the TEP region having been historically characterized as a region with suboptimal conditions for coral growth/development, there are important coral communities present. However, they do face seasonal upwelling, internal waves, high turbidity, eutrophic conditions, high interannual variation in seawater quality and frequent and intense ENSO events [12,13], all of which can negatively affect corals, decreasing their cover and therefore the available habitat and food supply for the crabs. Nevertheless, the TEP harbors well-developed, shallow coral communities, and the northern TEP is considered especially biodiverse $[14,15]$.

To date four Trapezia species have been recorded in the TEP: Trapezia digitalis and Trapezia ferruginea, which are widely distributed across the Indian and Pacific oceans and the endemic T. corallina and T. formosa [16]. Nevertheless, due to the almost imperceptible morphologic differences among species, some taxonomists have considered there to be only two [16]: T. corallina (synonymized with T. digitalis) and T. formosa (synonymized with both T. bidentata and T. ferruginea). Therefore, despite the existence of historical records of Trapezia within pocilloporid corals, their taxonomic classification remains unclear. Given (1) their importance to coral and coral reef health, (2) the inability to distinguish between putatively different species and (3) the need to understand whether certain crab species demonstrate specificity to (or a preference for) certain coral species, we sought to use morphometric and molecular taxonomic tools to better understand the ecology of the crab-coral symbiosis in the TEP.

\section{Materials and Methods}

\subsection{Study Site}

Trapezia spp. crabs were sampled from Pocillopora spp. colonies located in the Islas Marietas National Park (IMNP); a coral community located in the Central Mexican Pacific (CMP) region (Figure 1). This Natural Protected Area (NPA) harbors one of the most important coral communities of the Northeastern Tropical Pacific, one composed mainly of branching corals of the genus Pocillopora and massive and submassive corals of the genera Porites and Pavona. These three genera constitute most the hard coral cover [17] from $0 \mathrm{~m}$ to $20 \mathrm{~m}$, as is typical elsewhere in the TEP [18]. The NPA is an oceanographic transition area where three oceanic currents converge: the Costa Rican Coastal Current, the California Current and the water mass of the Gulf of California [19]. The surface ocean temperature ranges from 23 to $30^{\circ} \mathrm{C}$ during the year, with minimum and maximum values in March and September, respectively. Local conditions, such as upwelling and internal waves, cause the appearance of both daily fluctuations of up to $5^{\circ} \mathrm{C}$ [20] and of a thermocline at depths of up to $20 \mathrm{~m}$, resulting in highly variable conditions of sea temperature and dissolved oxygen $[19,21,22]$. This region is influenced by seasonal hurricanes, storms and natural stressors, and also by ENSO events that are associated with abnormal increases (El Niño) or decreases (La Niña) in surface temperature for several weeks or even months. Such temperature anomalies can affect the corals detrimentally, as can other environmental factors, such as altered $\mathrm{pH}$ and nutrient levels [23].

\subsection{Sampling and Taxonomic Identification}

Trapezia crabs were collected at three sites within IMNP (Figure 1). Each crab was obtained from a different Pocillopora colony at a depth of 5-7 m. Crabs were collected carefully (using metallic tweezers to extract them from the live coral colony) and immediately placed individually in 50-mL plastic tubes filled with seawater. Following collection, the crabs were preserved in $96 \%$ ethanol and transported to the laboratory. Crabs were then observed using a stereoscope (Stemi 508-Zeiss ${ }^{\circledR}$, Oberkochen, Germany) and classified to species level following the taxonomic criteria described by Castro [16,24]; carapace shape and size, color, cheliped size and propodus color were all considered. 
All crabs were photo-documented using a Canon Elph PowerShot 180 camera (Canon Inc., Tokyo, Japan), and, prior to long-term storage, a sample of muscle tissue was dissected from the cephalothorax and preserved in $96 \%$ ethanol for DNA extraction. Carapace and cheliped width and length were measured individually using Image J software (Open Source, Developed at the National Institutes of Health and the Laboratory for Optical and Computational Instrumentation, University of Wisconsin, Madison, WI, USA); values are expressed per species and sex as mean $\mathrm{mm} \pm$ standard deviation.

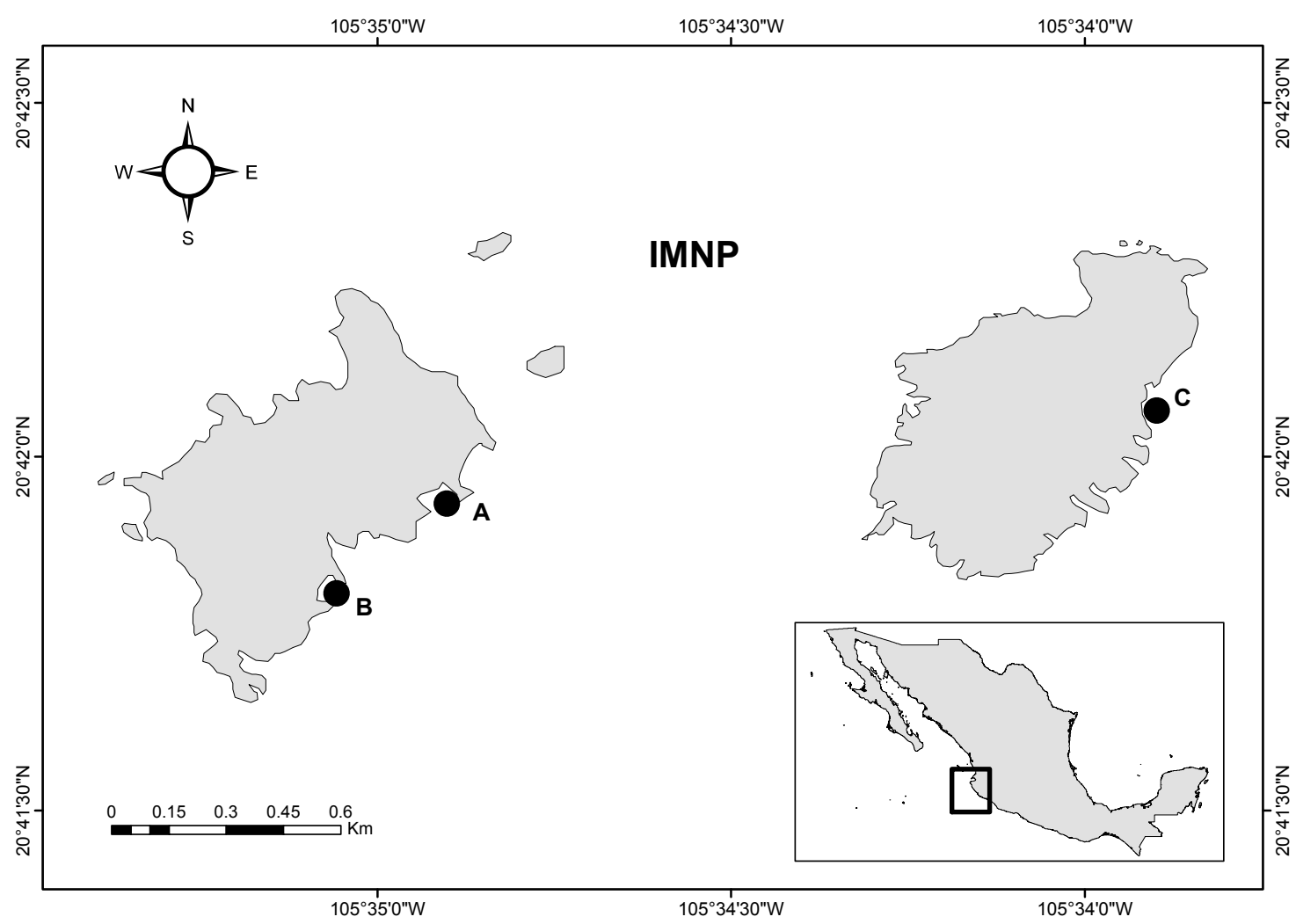

Figure 1. Study area in the Islas Marietas National Park (IMNP), Nayarit, Mexico, showing the location of sampling sites. All sampling sites have a high cover of Pocillopora sp. (15-33\%). (A) Zona de Restauración $\left(20.698860^{\circ} \mathrm{N}, 105.580997^{\circ} \mathrm{W}\right)$; (B) Cueva del Muerto $\left(20.697389^{\circ} \mathrm{N}, 105.582806^{\circ} \mathrm{W}\right)$ at Isla Larga; (C) Plataforma Pavonas $\left(20.700908^{\circ} \mathrm{N}, 105.565304^{\circ} \mathrm{W}\right)$ at Isla Redonda.

\subsection{DNA Extraction, Amplification and Sequencing}

Genomic DNA from the muscle tissue was extracted using the Wizard ${ }^{\circledR}$ Genomic DNA Purification kit (Promega, Madison, WI, USA) according to the manufacturer's protocol. Partial sequences of the nuclear gene histone $\mathrm{H} 3(\mathrm{H} 3)$ and the mitochondrial gene cytochrome c oxidase subunit 1 (cox1) were PCR amplified as follows: $\mathrm{H} 3$ gene fragments ( $347 \mathrm{bp}$ ) were amplified using the primers H3af 5'-ATGGCTCGTACCAAGCAGACVGC-3' and H3ar 5'-ATATCCTTRGGCATRATRGTGAC-3' of Lai et al. [25]. Cox 1 gene fragments $(600 \mathrm{bp})$ were amplified using the primers LCOI490 (5'-GGTCAACAAATCATAAAGAYATYGG-3') and HCOI21908 (5'-TAAACTTCAGGGTGACCAAAR AAYCA-3') from Folmer et al. [26]. PCR mix comprised 7.23 $\mu \mathrm{L}$ nuclease-free of $\mathrm{H}_{2} \mathrm{O}, 0.75 \mu \mathrm{L}$ of $\mathrm{MgCl}_{2}$, $0.66 \mu \mathrm{L}$ of dNTPs, $2.5 \mu \mathrm{L}$ of $10 \times$ buffer, $0.13 \mu \mathrm{L}$ of each primer, $0.10 \mu \mathrm{L}$ of Taq polymerase (Promega) and $1.2 \mu \mathrm{L}$ of DNA0. After an initial denaturation step at $94{ }^{\circ} \mathrm{C}$ for $5 \mathrm{~min}, 40$ cycles, comprising $94{ }^{\circ} \mathrm{C}$ for $1 \mathrm{~min}, 62^{\circ} \mathrm{C}$ for $1 \mathrm{~min}(\mathrm{H} 3)$ or $48.4^{\circ} \mathrm{C}$ for $1 \mathrm{~min}(\operatorname{cox} 1)$ and $72{ }^{\circ} \mathrm{C}$ for $1 \mathrm{~min}$, were carried out, with a final extension step of $5 \mathrm{~min}$ at $72{ }^{\circ} \mathrm{C}$.

PCR products were visualized on 2\%-TAE (Tris-acetate-EDTA) agarose gels. The final products were purified with the Wizard SV gel and PCR clean-up system (both from Promega) and sent to Macrogen, Inc. (Seoul, Korea). The forward and reverse sequences obtained were manually edited 
using Geneious Prime 2019.2.3 software in order to obtain a consensus sequence for each gene. To confirm the species identity, the consensus sequences were queried against the National Center for Biotechnology Information database (i.e., GenBank) via BLAST. Each gene sequence was submitted to NCBI with the following accession numbers: (H3) MT720697, MT720698, MT720699, MT720700, MT720701, MT720702, MT720703; (cox1) MN852247, MN852248, MN852249, MN852250, MN852251, MN852252, MN852253, MN852254.

Some additional sequences from members of the family Trapeziidae were obtained from GenBank and aligned with the sequences generated herein using Clustal W within Mega-X [27]. It is important to emphasize that, to date, there are no T. corallina and T. formosa $\mathrm{H} 3$ and cox 1 sequences available and that for T. bidentata no published H3 sequences exist. Molecular data sets ( $\mathrm{H} 3$ and cox1) were analyzed with maximum likelihood (ML) and Bayesian information (BI) methods.-ML analyses were performed using Mega-X software with 1000 bootstraps. TN93+G+I (Tamura-Nei model+gamma distributed rate of substitution+estimated proportion of invariant sites) was the best-fitting nucleotide substitution model for cox1, with T92+G (Tamura 3-parameter+gamma distributed rate of substitution) the ML best-fit for H3. Bayesian analyses were conducted with MrBayes v.3.1.2 [28] and appropriate DNA substitution models were determined separately for the $\mathrm{H} 3$ and cox 1 datasets. The Bayesian analysis was conducted by computing 10,000 Markov chain Monte Carlo generations with $7 \mathrm{H} 3$ and 8 cox 1 sequences. Using Mega-X software and cox 1 marker, pairwise genetic distances were calculated among the T. bidentata and T. formosa sequences from the present work, as well as T. bidentata sequences from GenBank. Finally, the species Kempina mikado (Crustacea: Stomatopoda) was used as the outgroup.

\section{Results}

\subsection{Morphologic Identification}

A total of 26 crabs were sexed and identified taxonomically based on coloration patterns, the shape of the cephalothorax and the size and shape of the chelipeds. Taxonomic characteristics based on Castro $[16,24]$ determined that the crabs belonged to three Trapezia species, and a mix of males, females and juveniles were obtained and described as follows (Figure 2): The crabs identified as T. formosa (3 females, 4 males) were all characterized as small adults, with cephalothoracic widths ranging from 4 to $7 \mathrm{~mm}$ (Table 1). They usually presented a reddish-orange color, with the lower margin of the propodus (chelipeds) yellowish and with chelipeds lengths 3-fold greater than widths (Table 1). Their carapaces were globose, with the anterolateral sides strongly curved (up to $45^{\circ}$; Figure 2A). The crabs identified as T. bidentata ( 7 females, 5 males and 1 juvenile) showed most of the morphologic characteristics of $T$. formosa with the key difference being that the specimens identified as T. bidentata showed a darker red coloration and presented less curved anterolateral sides of the carapace (Figure 2B); for this species the specimens examined presented higher carapace and cheliped sizes than T. formosa (Table 1). Finally, the crabs identified as T. corallina (5 males and 1 juvenile) presented a dark orange-brown color, brown reticulations on the propodus, and, in general, thick and bulky chelipeds; they were also characterized by a complete suture between the (i) second and third thoracic sternites and (ii) the ischium of the endognath of the third pair of maxillipeds; also, this species showed a rough appearance in the middle portion of the inner margin (Figure 2C). Finally, T. corallina presented both the largest cheliped and largest carapace of the species collected (Table 1).

Table 1. Trapezia carapace and cheliped measurements per species and sex. Values reported as means \pm SD. N/A corresponds to no available data.

\begin{tabular}{ccccccccc}
\hline \multirow{2}{*}{ Species } & \multicolumn{2}{c}{ Carapace Width } & \multicolumn{2}{c}{ Carapace Length } & \multicolumn{2}{c}{ Cheliped Width } & \multicolumn{2}{c}{ Cheliped Length } \\
\cline { 2 - 9 } & Males & Females & Males & Females & Males & Females & Males & Females \\
\hline Trapezia formosa & $6.10 \pm 0.99$ & $5.90 \pm 1.31$ & $5.06 \pm 0.64$ & $5.19 \pm 0.78$ & $2.54 \pm 0.50$ & $2.85 \pm 0.87$ & $6.41 \pm 1.27$ & $6.09 \pm 0.52$ \\
\hline Trapezia bidentata & $6.95 \pm 0.78$ & $8.93 \pm 2.43$ & $5.86 \pm 1.76$ & $6.32 \pm 1.91$ & $3.26 \pm 0.19$ & $3.15 \pm 1.52$ & $7.69 \pm 1.83$ & $6.156 \pm 0.921$ \\
\hline Trapezia corallina & $9.03 \pm 1.56$ & N/A & $8.17 \pm 3.01$ & N/A & $4.19 \pm 0.52$ & N/A & $9.78 \pm 2.33$ & N/A \\
\hline
\end{tabular}




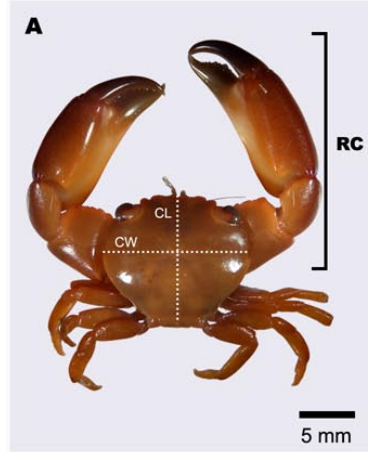

B

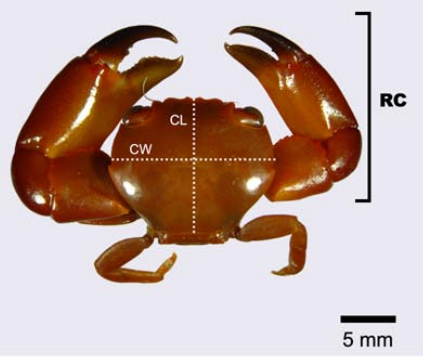

c

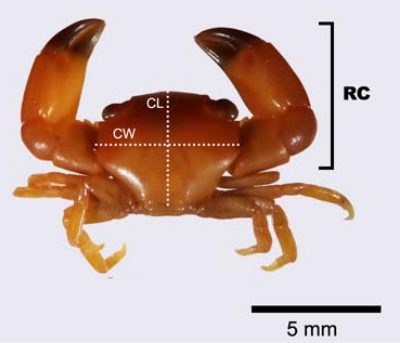

Figure 2. Trapezia crabs of the Tropical Eastern Pacific. (A) Trapezia formosa; (B) T. bidentata; (C) T. corallina . CW—carapace width; CL—carapace length; RC—right cheliped.

\subsection{Molecular Identification}

BLAST results revealed that all sequences analyzed $(n=15)$ were $99-100 \%$ similar to those of published sequences from the Trapezia genus on GenBank. Phylogenetic trees were built for each gene from the sequences obtained (Figures 3 and 4) within the Trapeziidae family: seven TEP H3 sequences (264 bp) and eight TEP cox 1 sequences (582 bp). Both ML and BI methods revealed that both molecular markers clustered the species T. bidentata and T. formosa into the same group; this result was also supported by high posterior probabilities and bootstrapping (Figures 3 and 4). T. corallina clustered with T. tigrina in a different, sister group. Pairwise genetic distances were zero between T. bidentata and T. formosa. When comparing cox 1 sequences from $T$. bidentata and $T$. formosa from the present work with those from T. bidentata obtained from GenBank, pairwise genetic distances were 0.001 .

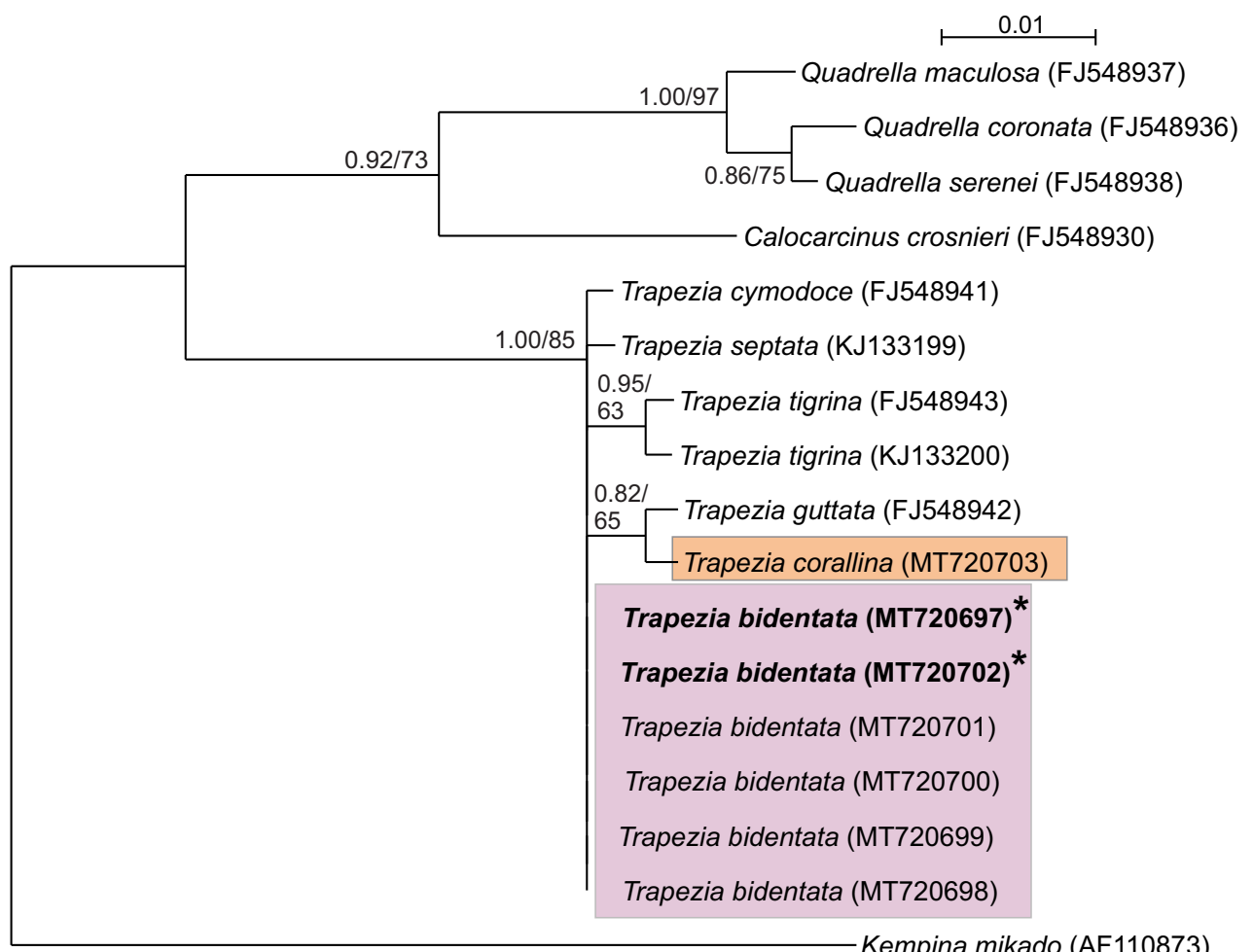

Figure 3. Consensus tree of the Trapeziidae family obtained using maximum likelihood and Bayesian information (BI) methods based on the $\mathrm{H} 3$ nDNA gene. Bootstrap values/posterior probabilities (ML/BI) are indicated under the principal node. Clade A: Quadrelliinae; B: Calocarciniinae; and C: Trapeziinae. Kempina mikado (Crustacea: Stomatopoda) was used as the outgroup. ${ }^{*}=$ Denotes sequences of crabs taxonomically identified as T. formosa. 


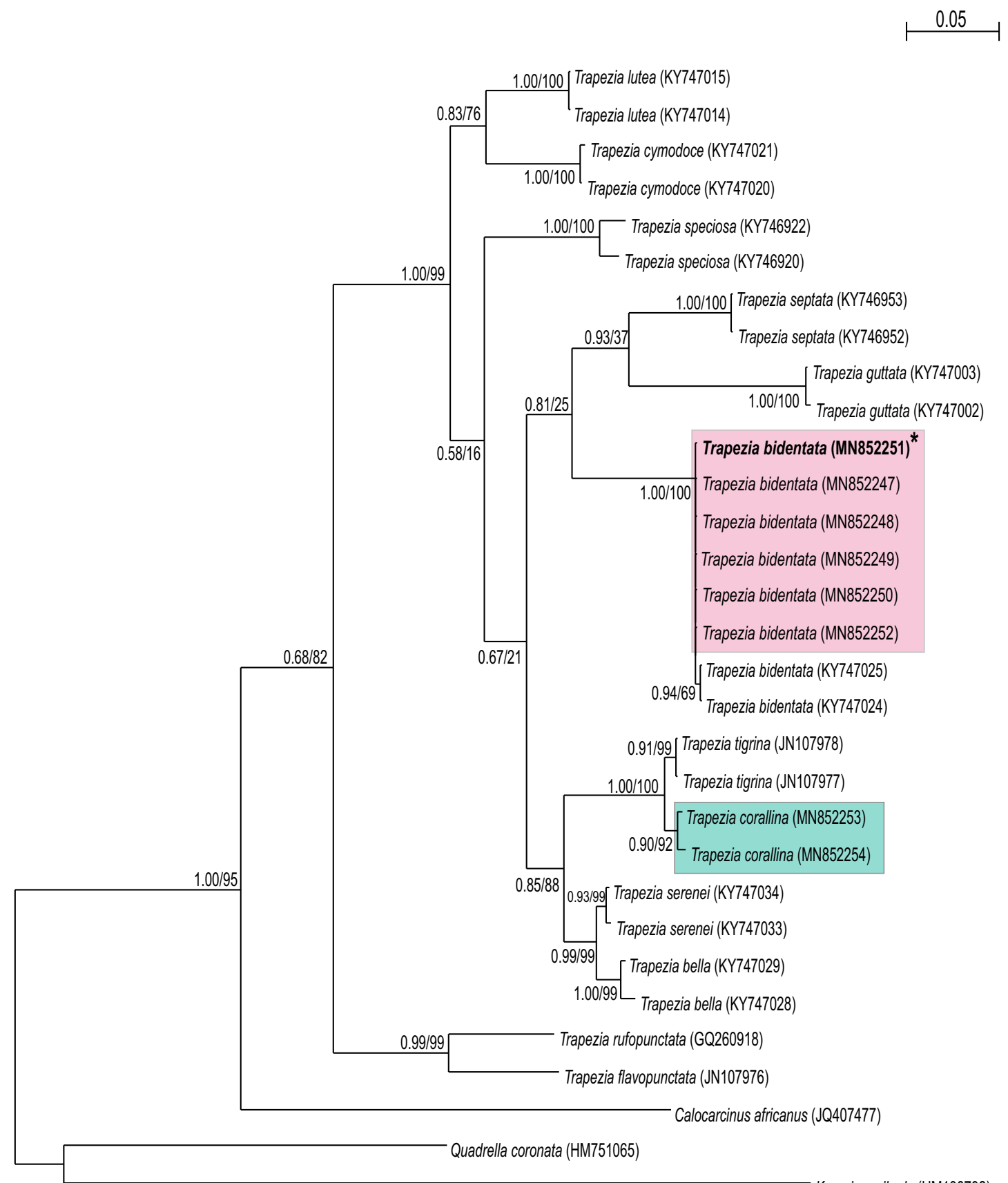

Figure 4. Consensus tree of the Trapeziidae family obtained using maximum likelihood and Bayesian information (BI) analyses based on the cox $1 \mathrm{mtDNA}$ gene. Bootstrap values/posterior probabilities (ML/BI) are indicated under the principal node. Clades A: Trapeziinae; B: Calocarciniinae; and C: Quadrelliinae. Kempina mikado (Crustacea: Stomatopoda) was used as the outgroup. ${ }^{*}=$ Denotes sequences of crabs taxonomically identified as T. formosa.

\section{Discussion}

The use of genetic tools for investigating crustacean phylogenetics is widespread and both cox 1 and $\mathrm{H} 3$ have proven suitable for resolving crab identities to species level $[25,29,30]$. By comparing cox1 sequences of specimens with published available data for related taxa, we identified two clades: T. corallina and T. bidentata. The cox1 mitochondrial gene, while overall highly conserved [31], contains a hyper-variable region that is useful for taxonomy. By performing the same procedure with the $\mathrm{H} 3$ 
gene, the same two clades were resolved: T. corallina and T. bidentata. The $\mathrm{H} 3$ nuclear gene evolves more slowly than mitochondrial genes [32], but nevertheless corroborated the cox 1 findings.

The delimitation of species is problematic for recently diverged lineages that are not yet morphologic distinct. Furthermore, phenotypic convergence can also lead to low morphologic divergence [33]. The integrative use of morphologic (traditional taxonomy) and genetic identification approaches employed herein could be extended to include behavioral and ecological characteristic [34,35] so as to serve as an even more holistic identification method. Using traditional taxonomic characterizations alone, T. corallina, T. formosa and T. bidentata were considered three different species. This conclusion was based on taxonomical parameters that were generally considered valid for discrimination between decapod species: the shape of the carapace, chelipeds and external coloration $[24,25,36-39]$. However, the molecular data support the conclusion that $T$. formosa is a morphotype of the species T. bidentata and thus should not be considered as a separate species.

Accurate identification of members of the Trapezia genus is of value not only for the future study of decapods, but also for study of their coral hosts. Pocillopora is considered the main reef-builder of the TEP region [40-42] and, unlike dominant corals in other parts of the Indo-Pacific, are markedly resilient to environmental change [43,44]. Given that adult healthy colonies seem always to be associated with at least one Trapezia sp. crab, it is possible that this high acclimatization capacity is linked to crab presence $[40,45]$. It is nevertheless unclear what implications future climate change-driven impacts will have on this mutualistic symbiosis and a more rigorous assessment of ecological implications of crab-coral mutualism in the TEP would be of value. In this case additional molecular markers and other traits (e.g., behavior or physiology of the crabs) could be incorporated into an investigation in order to gain new insights, including into the role of commensals in promoting resilience of the TEP's coral communities.

Author Contributions: H.M.C.-F., A.P.R.-T., A.L.C.-M. and E.B.-G. carried out the research. H.M.C.-F. and E.B.-G. analyzed the data. A.P.R.-T., E.B.-G. and A.L.C.-M. contributed reagents, laboratory equipment and analytical tools. H.M.C.-F., A.P.R.-T. and E.B.-G. wrote the manuscript. All authors have read and agreed to the published version of the manuscript.

Funding: HMCF was funded by a doctoral fellowship from the Consejo Nacional de Ciencia y Tecnologia (CONACYT-No. 632506). The present work was supported by the National Geographic Society (NGS-55349R-19 to APRT) and the project "Programa Integral de Fortalecimiento Institucional" of the Universidad de Guadalajara (P/PIFI-2010-14MSU0010Z-10 to ACM).

Acknowledgments: The authors thank Ismael Huerta for image editing and Peter Castro for advice on crab identification. A special thanks to Vladimir Pérez and Jeimy Santiago for their help in field and laboratory work. In addition, we thank the authorities of the Islas Marietas National Park (CONANP) for their assistance with field operations. Finally, we thank to Anderson Mayfield and Rupert Ormond for the English proofreading of the manuscript.

Conflicts of Interest: The authors declare no conflict of interest.

\section{References}

1. Richter, C.; Wunsch, M.; Rasheed, M.; Koetter, I.; Badran, M.I. Endoscopic exploration of Red Sea coral reefs reveals dense populations of cavity dwelling sponges. Nature 2001, 413, 726-730. [CrossRef] [PubMed]

2. Stella, J.S.; Pratchett, M.; Hutchings, P.; Jones, G. Coral-associated invertebrates: Diversity, ecological importance and vulnerability to disturbance. Oceanogr. Mar. Biol. 2011, 49, 43-104.

3. Gagnon, J.M.; Beaudin, L.; Silverberg, N.; Mauviel, A. Mesocosm and in situ observations of the burrowing shrimp Calocaris templemani (Decapoda: Thalassinidea) and its bioturbation activities in soft sediments of the Laurentian Trough. Mar. Biol. 2013, 160, 2687-2697. [CrossRef]

4. Rice, M.M.; Ezzat, L.; Burkepile, D.E. Corallivory in the Anthropocene: Interactive effects of anthropogenic stressors and corallivory on coral reefs. Front. Mar. Sci. 2018, 5, 525. [CrossRef]

5. Cortés, J. Marine biodiversity baseline for Área de Conservación Guanacaste, Costa Rica: Published records. ZooKeys 2017, 652, 129. [CrossRef] [PubMed]

6. Weber, J.N.; Woodhead, P.M. Ecological studies of the coral predator Acanthaster planci in the South Pacific. Mar. Biol. 1970, 6, 12-17. [CrossRef] 
7. Garth, J.S. The Crustacea Decapoda (Brachyura and Anomura) of Eniwetok Atoll, Marshall Islands, with special reference to the obligate commensals of branching corals. Micronesica 1964, 1, 137-144.

8. Stimson, J. Stimulation of fat-body production in the polyps of the coral Pocillopora damicornis by the presence of mutualistic crabs of the genus Trapezia. Mar. Biol. 1990, 106, 211-218. [CrossRef]

9. Glynn, P.W. Fine-scale interspecific interactions on coral reefs: Functional roles of small and cryptic metazoans. Smithson. Contr. Mar. Sci. 2013, 39, 229-248.

10. Patton, W.K. Community structure among the animals inhabiting the coral Pocillopora damicornis at Heron Island Australia. In Symbiosis in the Sea, 1st ed.; Vernberg, W., Ed.; Univ. South Carolina Press: Columbia, SC, USA, 1974; pp. 219-243.

11. Garth, J.S. Decapod crustaceans inhabiting reef-building corals of Ceylon and the Maldive Islands. J. Mar. Biol. Assoc. India. 1974, 15, 195-212.

12. Nyenzi, B.; Lefale, P.F. El Nino southern oscillation (ENSO) and global warming. Adv. Geosci. 2006, 6, 95-101. [CrossRef]

13. Glynn, P.W.; Alvarado, J.J.; Banks, S.; Cortés, J.; Feingold, J.S.; Jiménez, C.; Maragos, J.E.; Martínez, P.; Maté, J.L.; Moanga, D.A.; et al. Eastern Pacific Coral Reef Provinces, Coral Community Structure and Composition: An Overview. In Coral Reefs of the Eastern Tropical Pacific, 1st ed.; Glynn, P., Manzello, D., Enochs, I., Eds.; Springer: Dordrecht, The Netherlands, 2017; Volume 8, pp. 107-176. [CrossRef]

14. Richmond, R.H. Energetics, competency, and long-distance dispersal of planula larvae of the coral Pocillopora damicornis. Mar. Biol. 1987, 93, 527-533. [CrossRef]

15. Toth, L.T.; Aronson, R.B.; Vollmer, S.V.; Hobbs, J.W.; Urrego, D.H.; Cheng, H.; Enochs, I.C.; Combosch, D.J.; van Woesik, R.; Macintyre, I.G. ENSO drove 2500-year collapse of eastern Pacific coral reefs. Science 2012, 337, 81-84. [CrossRef] [PubMed]

16. Castro, P. Eastern Pacific species of Trapezia (Crustacea, Brachyura: Trapeziidae), sibling species symbiotic with reef corals. Bull. Mar. Sci. 1996, 58, 531-554.

17. Reyes-Bonilla, H.; Calderón Aguilera, L.E.; Cruz-Piñón, G.; Medina-Rosas, P.; López-Perez, R.A.; Herrero-Perezrul, M.D.; Leyte-Morales, G.E.; Cupul-Magaña, A.L.; Carriquiry-Beltran, J.D. Atlas de Corales Pétreos (Anthozoa: Scleractinia) del Pacífico Mexicano, 1st ed.; Sociedad Mexicana de Arrecifes Coralinos AC, CICESE, CONABIO, CONACYT, DBM/UABCS, CUC/UdeG, Umar: Mexico City, México, 2005; p. 129.

18. CONANP (Comisión Nacional de Áreas Naturales Protegidas). Programa de Conservación Y Manejo; Parque Nacional Islas Marietas: Mexico City, México, 2007.

19. Wyrtki, K. Surface currents of the eastern tropical Pacific Ocean. Bull. Inter. Am. Trop. Tuna Commn. 1965, 9, 268-305.

20. Roden, G.I.; Groves, G.W. Recent oceanographic investigations in the Gulf of California. J. Mar. Res. 1959, 18, 10-35.

21. Griffiths, R.C. Physical, chemical and biological oceanography at the entrance to the Gulf of California, spring of 1960. US Fish. Wild. Serv. Spec. Sci. Rep. Fish. 1968, 573, 1-47.

22. Fiedler, P.C. Seasonal climatologies and variability of eastern tropical Pacific surface waters. NOAA Tech. Rep. 1992, 109, 1-65.

23. Wang, C.; Fiedler, P.C. ENSO variability and the eastern tropical Pacific: A review. Prog. Oceanogr. 2006, 69, 239-266. [CrossRef]

24. Castro, P.; Ng, P.K.; Ahyong, S.T. Phylogeny and systematics of the Trapeziidae Miers, 1886 (Crustacea: Brachyura), with the description of a new family. Zootaxa 2004, 643, 1-70. [CrossRef]

25. Lai, J.C.; Ahyong, S.T.; Jeng, M.S.; Ng, P.K. Are coral-dwelling crabs monophyletic? A phylogeny of the Trapezioidea (Crustacea: Decapoda: Brachyura). Invertebr. Syst. 2009, 23, 402-408. [CrossRef]

26. Folmer, O.; Black, M.; Hoeh, W.; Lutz, R.; Vrijenhoek, R. DNA primers for amplification of mitochondrial cytochrome c oxidase subunit I from diverse metazoan invertebrates. Mol. Mar. Biol. Biotech. 1994, 3, $294-299$.

27. Kumar, S.; Stecher, G.; Li, M.; Knyaz, C.; Tamura, K. MEGA X: Molecular evolutionary genetics analysis across computing platforms. Mol. Biol. Evol. 2018, 35, 1547-1549. [CrossRef] [PubMed]

28. Ronquist, F.; Huelsenbeck, J.P. MrBayes 3: Bayesian phylogenetic inference under mixed models. Bioinformatics 2003, 19, 1572-1574. [CrossRef]

29. Moritz, C. Defining 'evolutionarily significant units' for conservation. Trends. Ecol. Evol. 1994, 9, 373-375. [CrossRef] 
30. da Silva, J.M.; Creer, S.; Dos Santos, A.; Costa, A.C.; Cunha, M.R.; Costa, F.O.; Carvalho, G.R. Systematic and evolutionary insights derived from mtDNA COI barcode diversity in the Decapoda (Crustacea: Malacostraca). PLOS ONE 2011, 6, e19449. [CrossRef]

31. Fransen, C.H.J.M.; De Grave, S. Evolution and Radiation of Shrimp-Like Decapods: An Overview. In Decapod Crustacean Phylogenetics (Crustacean Issues Book 18), 1st ed.; Martin, J.W., Crandall, K.A., Felder, D.L., Eds.; Taylor \& Francis/CRC Press: Boca Raton, FL, USA, 2016; pp. 245-259.

32. Moriyama, E.N.; Powell, J.R. Synonymous substitution rates in Drosophila: Mitochondrial versus nuclear genes. J. Mol. Evol. 1997, 45, 378-391. [CrossRef] [PubMed]

33. Niemiller, M.L.; Near, T.J.; Fitzpatrick, B.M. Delimiting species using multilocus data: Diagnosing cryptic diversity in the Southern cavefish, Typhlichthys subterraneus (Teleostei: Amblyopsidae). Evolution 2012, 66, 846-866. [CrossRef] [PubMed]

34. Wenzel, J.W. Behavioral homology and phylogeny. Annu. Rev. Ecol. Evol. Syst. 1992, 23, 361-381. [CrossRef]

35. Miller, J.S.; Wenzel, J.W. Ecological characters and phylogeny. Annu. Rev. Entomol. 1995, 40, 389-415. [CrossRef]

36. Castro, P. Notes on symbiotic decapod crustaceans from Gorgona Island, Colombia, with a revision of the eastern Pacific species of Trapezia (Brachyura, Xanthidae), symbionts of scleractinian corals. An. Inst. Inv. Mar. Punta Betín 1982, 12, 9-17. [CrossRef]

37. Castro, P. Shallow-water Trapeziidae and Tetraliidae (Crustacea: Brachyura) of the Philippines (Panglao 2004 Expedition), New Guinea, and Vanuatu (Santo 2006 Expedition). Raffles Bull. Zool. 2009, 20, 271-281.

38. Castro, P. Systematic status and geographic distribution of Trapezia formosa Smith, 1869 (Crustacea, Brachyura, Trapeziidae), a symbiont of reef corals. Zoosystema 1998, 2, 177-181.

39. Cabezas, P.; Macpherson, E.; Machordom, A. Taxonomic revision of the genus Paramunida Baba, 1988 (Crustacea: Decapoda: Galatheidae): A morphological and molecular approach. Zootaxa 2010, 1, 1-60. [CrossRef]

40. Glynn, P.W. Some physical and biological determinants of coral community structure in the eastern Pacific. Ecol. Monogr. 1976, 4, 431-456. [CrossRef]

41. Jiménez, C.; Cortés, J. Growth of seven species of scleractinian corals in an upwelling environment of the eastern Pacific (Golfo de Papagayo, Costa Rica). Bull. Mar. Sci. 2003, 1, 187-198.

42. Reyes-Bonilla, H. Coral reefs of the Pacific coast of Mexico. In Latin American Coral Reefs, 1st ed.; Cortés, J., Ed.; Elsevier Science: Amsterdam, The Netherlands; London, UK, 2003; pp. 331-349. [CrossRef]

43. Rodríguez-Troncoso, A.P.; Carpizo-Ituarte, E.; Cupul-Magaña, A.L. Physiological response to high temperature in the Tropical Eastern Pacific coral Pocillopora verrucosa. Mar. Ecol. 2016, 37, 1168-1176. [CrossRef]

44. Martínez-Castillo, V.; Rodríguez-Troncoso, A.P.; Santiago-Valentín, J.D.; Cupul-Magaña, A.L. The influence of urban pressures on coral physiology on marginal coral reefs of the Mexican Pacific. Coral Reef. 2020, 39, 625-637. [CrossRef]

45. Knudsen, J.W. Trapezia and Tetralia (Decapoda, Brachyura, Xanthidae) as obligate ectoparasites of pocilloporid and acroporid corals. Pac. Sci. 1967, 21, 51-57.

(C) 2020 by the authors. Licensee MDPI, Basel, Switzerland. This article is an open access article distributed under the terms and conditions of the Creative Commons Attribution (CC BY) license (http://creativecommons.org/licenses/by/4.0/). 